\section{Ukrainian Journal \\ of Educational Studies and Information Technology}

ISSN: 2521-1234 online

doi: 10.32919/uesit.2019.03.04

Vol. 7, Issue 3, 2019

UDC 378.018.43.046-021.68-051:004

\title{
The use of information and communication technology in supervising open and distance learning PhD students
}

\author{
Promise Zvavahera ${ }^{1}$, Fine Masimba ${ }^{2}$ \\ ${ }^{1}$ Reformed Church University, \\ Masvingo, Zimbabwe \\ ${ }^{2}$ Catholic University of Zimbabwe, \\ Harare, Zimbabwe
}

\begin{tabular}{|c|c|}
\hline ARTICLE INFO & ABSTRACT \\
\hline History: & \multirow{19}{*}{$\begin{array}{l}\text { Even though open and distance learning (ODL) using Information } \\
\text { and Communication Technologies can be applied across disciplines } \\
\text { and at various levels, this paper focuses on the supervision of PhD } \\
\text { students studying through the Open and Distance Learning mode of } \\
\text { education using Information and Communication Technologies } \\
\text { (ICTs). Taking into account the fact that higher education } \\
\text { institutions are always striving to increase the quality of supervision } \\
\text { and throughput of doctoral programmes, the study highlights how } \\
\text { Information and Communication Technologies (ICTs) can mitigate } \\
\text { these challenges. The study was carried out in } 10 \text { Zimbabwean } \\
\text { universities to evaluate the levels of preparedness of universities, } \\
\text { supervisors and PhD students in using information and } \\
\text { communication technology during their studies. Purposive sampling } \\
\text { was used focusing on PhD students studying through ODL, local } \\
\text { universities offering PhD programmes experienced, PhD supervisors, } \\
\text { the Zimbabwe Council for Higher Education officials and officials } \\
\text { from the Ministry of Higher and Tertiary Education, Science and } \\
\text { Technology Development. Students, universities and supervisors } \\
\text { were not fully prepared to do their work using ICTs due to various } \\
\text { reasons. Some of the reasons given were that some universities did } \\
\text { not have the required infrastructure and facilities in place. Some of } \\
\text { the supervisors and students lacked basic computer skills and this } \\
\text { affected the quality of supervision and slowness in giving feedback. } \\
\text { The lack of internet availability and poor connectivity were also } \\
\text { cited as challenges especially with the prevailing load shedding. The } \\
\text { study recommends universities to invest in ICTs infrastructure since } \\
\text { higher education transcends geographical boundaries. }\end{array}$} \\
\hline Received: 01.09.2019 & \\
\hline Accepted: 25.09.2019 & \\
\hline Published online: 30.09 .2019 & \\
\hline Keywords: & \\
\hline information and communication & \\
\hline $\begin{array}{l}\text { technology } \\
\text { open and distance learning } \\
\text { supervision }\end{array}$ & \\
\hline $\begin{array}{l}\text { (C) P. Zvavahera, } \\
\text { F. Masimba }\end{array}$ & \\
\hline This work is licensed under a "CC BY & \\
\hline 4.0" license. & \\
\hline & \\
\hline & \\
\hline & \\
\hline & \\
\hline & \\
\hline & \\
\hline & \\
\hline & \\
\hline & \\
\hline
\end{tabular}




\section{INTRODUCTION}

The high demand for PhDs in Africa and across the globe, have witnessed high numbers of $\mathrm{PhD}$ students entering universities (Frick, 2011; Gatfield, 2005). ODL has become popular across the globe because of its flexibility and low cost (Gaba, 2004). ICT takes care of time, distance between the student and the university, location, socio-economic issues and communication between the student and supervisor throughout the world (Willems et al., 2013). ICT has greatly assisted ODL to remove barriers to access to higher education, allows for easy access to learning materials, flexibility and facilitates the student to quickly develop into an independent researcher. For ODL to be successful and beneficial to postgraduate students, a combination of distance learning and ICT is key. This mode of learning is student-centred and there is recognition of diversity in learning styles considering the students' requirements and other factors that impact on the learning environment. In doing all this, mechanisms are put in place to make sure that quality is not compromised. ODL makes optimum use of the limited supervisors available in universities. It also deals with cultural differences across the geographical space. In view of this, it is therefore critical to assess the levels of preparedness of universities, $\mathrm{PhD}$ students and supervisors to use ict during their studies.

ODL is defined as a way of education that focuses on all aspects of open learning whereby learners are given access to education and training through a flexible learning environment irrespective of time, space and place (Ghosh et al., 2012). ODL is mainly characterised by the physical distance between the student and the university and the absence of face-to-face interaction between the supervisor and the student. ODL differs from blended learning, which combines both distance learning and faceto-face interaction in varying proportions. Universities that use the ODL mode of learning use a blend of traditional ways of delivering modules and learning materials to the learner physically or electronic affordances notably ICTs. Cross and Backhouse (2014) note that the traditional supervision methods can no longer meet the needs of a diversified student population and this has led to innovation by complementing ODL with ICT so that students from all walks of life can have the opportunity to enrol for a PhD programme.

Open and distance learning has been in existence since time immemorial. Pitman first introduced ODL in 1844 (Tait, 2003). The University of London followed the trend in 1858 by offering a variety of degree programmes (Bell, \& Tight, 2003). The United States of America followed suit in 1873 by introducing the 'Society to Encourage Studies at Home' programme (Levinson, 2005; Pittman, 2006). The University of London started offering masters and $\mathrm{PhD}$ degrees in 1969, the University of Athabasca in 1972 and Germany established its Open Distance Education in 1974 (University of London, 2012). The recent trends have witnessed the sprouting of ODL institutions of higher learning across the globe due to its flexibility and affordability (Guilar, \& Lorring, 2008; Mouton, 2011). This mode of education is more suitable to students who cannot attend lectures full-time for various reasons (Wisker et al., 2003). By their very nature, ODL institutions of higher learning provide educational opportunities to mature nontraditional, working students who are often unable to access higher education on full-time, contact, and campus-based institutions.

Information and Communication Technology is defined as the technology responsible for using all telecommunications responsible for audiovisual processing and transmission systems, intelligent building management systems, broadcast media, monitoring functions and network-based control (Zuppo, 2012). ODL is distinct from online education, which entails the use of ICTs to facilitate learning regardless of whether the learner and the supervisor are separated by physical distance wholly (ODL) or partially as in the case of blended learning. The use of ICTs in ODL doctoral supervision capitalises on three interactive processes: student and content, student and supervisor and student and student (Moore, 1989). Because doctoral candidates are confronted with similar challenges, ICTs facilitate enrichment of ideas and the creation of virtual classes and groups.

Traditionally, ODL relied on the use of modules and other training materials that were 
mailed to learners. The advent of information and communications technology (ICT) revolutionised and revitalized ODL. For instance, the University of South Africa, University of London and the Zimbabwe Open University are some of the institutions of higher learning offering $\mathrm{PhDs}$ through the ODL mode of learning blended with ICTs. These universities have been offering $\mathrm{PhD}$ programmes successfully since their inception. Their qualifications are highly regarded on the international labour market. ODL is taking over the traditional delivery methods by storm. For instance, the Zimbabwe Open University broke the record by graduating fourteen (14) $\mathrm{PhDs}$ in 2018. This is a success story since universities that offer full-time $\mathrm{PhD}$ programmes in Zimbabwe have graduated on average five PhDs per year. These are some of the success stories that can be told about Africa higher education.

Before the advent of ICT facilitated ODL, postgraduate studies was a preserve of the chosen few who could afford, thanks to ICT evolution which provided an opportunity to those who could not acquire a $\mathrm{PhD}$ due to physical limitations, work and family commitments (Barket, \& Holley, 1996). This mode of education allows for flexibility since the student can determine the place and time of study. ODL has the potential of providing inclusive and equitable access to higher education by making sure that all those who want to study for a $\mathrm{PhD}$ can be afforded the opportunity. ODL also has the potential of internationalising higher education since it creates no boundaries in terms of student recruitment and supervision. Students can be enrolled from anywhere around the globe as long as they qualify and they can be supervised by anyone around the globe as well.

The use of ICT has created virtual classes and learning groups. This has also prompted timeous feedback, effective and efficient communication between supervisors and the students. ODL complemented by ICT facilitates the creation of communities of scholars through networking and sharing of information and experiences. There is also flexibility in the working hours and completion duration since the programme is selfpaced.

ODL addresses issues of inclusivity, giving the opportunity to women and other less privileged groups in society access to higher education. Working individuals who cannot register fulltime can also enroll through distance education and acquire a recognised $\mathrm{PhD}$. It is also suitable for those who are in areas ravaged with wars, violence or displaced. Students in remote areas can also enroll for the postgraduate programmes since distance is no longer a barrier, thanks to ICT.

The rapid increase in information technology around the globe has led to the increase of $\mathrm{PhD}$ students studying through distance teaching (Erichsen, Bolliger, \& Halupa, 2014). This allows access to information and flexibility to both the student and the supervisor. This further allows the use of video conferencing and virtual classes. According to a study that was carried out by Erichsen et al., (2014) students who were in the blended type of learning were found to be more satisfied that those on full-time. What needs to be appreciated is that technology is there to enhance supervision and make learning exciting. Supervisors can also be engaged to students who apply to read for their PhDs through ODL. Students enrol on a part-time basis as matter of choice or some would have failed to complete their programmes on time. Others could be part of the university academic staff and therefore, enrol on a part-time basis could be the most ideal. The relationships between the supervisor and the supervisee have to be a mutual one in order to make meaningful progress.

ODL is not without its own challenges. Universities are compelled to increase their throughput at $\mathrm{PhD}$ level yet they face the daunting task of maintaining high quality for the same (Mouton, 2011). Manyike (2017) notes that the task of supervising through distance education is even more challenging since this mode of supervision restricts face-to-face interaction between the supervisor and the student. Failure for face-to-face interaction with other students and the supervisor may affect the students' critical thinking which is important at $\mathrm{PhD}$ level (Picard, Wilkinson, \& Wirthensohn, 2011). This then implies that whatever mechanisms are put in place, quality should not be compromised. Since there is no direct conduct between the supervisor and the student, delayed feedback can affect the progress of the student (Barket, \& Holley, 1996). Time lapse is a serious 
limiting factor to the student. Accordingly, scholars advice that there is need for serious engagement on the part of the student in order to complete the programme.

In order to achieve the desired outcomes, the relevant hardware and software have to be in place. What it means is that a supervisor can have students situated anywhere around the globe as long as both of them have internet connectivity and the required ICTs infrastructure and facilities. One of the challenges is that of the physical distance between the supervisor and the student and issues related to ICTs affordability and accessibility. What it means is that both parties need to have reliable networks and compatible infrastructure in order to have effective communication. Hardware and software that are put in place should be easily accessible and simple to use (Maor, Ensor, \& Fraser, 2016). Lazarus and Folkman (1984) note challenges of inadequate online ICT support systems for $\mathrm{PhD}$ students and this affects the quality of the final product. This translates to insufficient information and communication that normally leads to emotional tension, worriment and lack of control of the situation. This notation is further buttressed by (Haksever, \& Manisali, 2000) found that lack of structured or insufficient communication channels resources were found to be the major source of discomfort for $\mathrm{PhD}$ students. Lack of feedback, insufficient information and poor support from the supervisors and the university affects the quality of the outcome and completion time (Jones, 2013).

For a student to make meaningful progress there is need for motivation, imitative and commitment (Allen, Stucky, \& Thiele, 1999). The creation of a virtual office by the supervisor is critical in making sure that the supervisor takes cognisance of time differences in order to attend to all students' queries. In order to have progress, the supervisor and the student should agree on deadlines for submission of the agreed work. The supervisor should send reminders to the student now and again. The creation of an email list becomes handy since it facilitates the sharing of information among group members.

One of the limitations to both the students and supervisors is the assumed limited appreciation of basic computer skills and the use of the internet and other web technologies. Some experienced and old supervisors cannot use a computer and under such circumstances, communication and feedback becomes a challenge. Interruption of internet services due to various reasons inclusive of power outages, technical hitches (Mafa, \& Mapolisa, 2012) or the blocking of internet in the case of Zimbabwe from 14 January - 16 January 2019, during recent demonstrations can adversely affect progress of the student and quality of supervision (City Press, 2019).

It is also costly to put in place and maintain the infrastructure and hardware since the students can work from their homes or offices (Allen, Stucky, \& Thiele, 1999). Further to the above, information and communication technology is rapidly changing and this may affect the student in the midst of their studies. The hardware (computers, printers and related software) are expensive and this may be a setback for the student since he/she will not be resident at the campus (Nasisri, \& Mafakheri, 2015; Mapesela, \& Wilkinson, 2005; Picard, Wilkinson, \& Wirthensohn, 2011).

Even though supervisors have diverse backgrounds, experiences and expertise, supervising through $\mathrm{ODL}$ at $\mathrm{PhD}$ level continues to be a challenge (Pearce, 2005). However, even though there are challenges, some supervisors are comfortable in supervising in such environments. Challenges that are faced by ODL research supervisors and full-time supervisors are slightly different from those experienced by supervisors in conventional universities. It has also been noted that lack of regular consultations with supervisors may lead to lack of progress. This then defeats the whole purpose of integrating distance supervision with information and communication technology. The quality of supervision is dependent on the quality of communication and understanding between the student and the supervisor.

Confidentiality and privacy are issues of concern in research. Since the supervisor and student use the internet to communicate, they must make sure that the information they exchange is secure as this may infringe on privacy. In accordance with the Singapore 
Statement on Research Integrity, research should not be carried out at the expense of the public (Second World Conference on Research Integrity, 2010). What is critical is to make sure that the system prevents unauthorized access and disclosure of information and this directly deals with information flow. The issue of plagiarism becomes important since the student will be using information from the internet.

There is a misconception that supervision through distance is easy and supervisors end up being overloaded with work. This compromises the quality of supervision. The supervisor could be having some other work other than supervising ODL students and the department members may not recognise this. Work overload could also emanate as a result that supervisors are always available to their students regardless of time differences since students are enrolled from round the globe. Further to that, the supervisor represent the university in most areas for instance, the supervisor needs to be in constant touch with the IT Department as well as providing information on library services and other information that may be requested by the student.

Students studying for PhDs through ODL have cited challenges such as long periods to complete and high rate of dropouts. Further to that, issues of lack of ICTs infrastructure and facilities have been raised. This study seeks to path to investigate practical ways of addressing the said challenges. Given that higher education institutions are always striving to increase the quality of supervision and throughput of doctoral programmes, this study highlights how Information and Communication Technology (ICT) can mitigate these challenges. The essay concludes by proffering lessons learnt from ODL facilitated ODL doctoral research supervision practices and to propose areas for future research.

Objectives of the study. The specific objectives of the study were to:

1. Assess the level of preparedness by $\mathrm{PhD}$ students in using ICT in their studies.

2. Assess the level of preparedness by $\mathrm{PhD}$ supervisors in using ICT in supervision.
3. Assess the level of preparedness by universities in assisting $\mathrm{PhD}$ students in their studies using ICT.

4. Propose a comprehensive model of using ICTs in Supervising Open and Distance Learning PhD Students.

\section{METHODOLOGY}

This section describes the methodologies and tools that were used to carry out the study. The study used both quantitative and qualitative research designs. The methodology employed face-to-face interviews with all the respondents. The idea was to get an in-depth understanding of the levels of preparedness by $\mathrm{PhD}$ students, $\mathrm{PhD}$ supervisors and universities in using ICTs to maintain quality and throughput of $\mathrm{PhDs}$.

\section{SAMPLING}

Purposive non-probability sampling is a sampling method that produces a purposive nonprobability sample. This study follows Kumar (2011) who use the term purposive sampling to refer to this method and a purposive sample to refer to the sample that comes out of this method. The researcher only approached people who met certain criteria based on the researcher's consideration on whether the data provided would meet the objectives of the study. In this case, $\mathrm{PhD}$ students studying through ODL, experienced $\mathrm{PhD}$ supervisors, ZIMCHE Official, senior universities officials and officials from the Ministry of Higher and Tertiary Education.

Population and Sample size. The criteria for coming up with the sample were:

- Individuals studying for PhD through ODL;

- Individuals supervising PhD students;

- Individuals with experience in ODL mode of learning.

The following categories of respondents were involved in the study:

- Ten PhD supervisors;

- Ten PhD students;

- One Zimbabwe Council for Higher education Official (Registers and monitor quality in the country's institutions of higher learning); 
- Two senior officers in the Ministry of Higher and Tertiary Education responsible for university education;

- Ten senior officials, one from each university.

The study sample was therefore 24 . Narratives and statistical data were used to analyse the data.

\section{FINDINGS AND DISCUSSION}

The following sections present and discuss the findings of the study at three levels:

- Level of preparedness by lecturers;

- Level of preparedness by students;

- Level of readiness by universities.

Level of preparedness by lecturers. The study noted that even though all universities under the study had ICT infrastructure and facilities in place, most of the universities did not have proper systems in place to supervise students across the breadth and width of the world. It was further noted that most lecturers who were above 60 years of age were immune to using ICT in their daily work let alone for supervision purposes. It was noted that their secretaries and colleagues read out emails to them and then responded. This alone could delay giving feedback and compromised on the quality of feedback to students. It was further noted that universities did not have reasonable lines of communication with students as most universities were found to be using emails most instead of other forms such as skype. This finding concurs with Haksever \& Manisali (2000) who found that lack of structured or insufficient communication channels resources were the major source of discomfort for $\mathrm{PhD}$ students.

In view of this, universities should come up with refresher courses for all university lecturers and supervisors and continue to build awareness on the importance of ICTs in a world that is technologically driven. There was consensus that such an initiative could go a long way in closing the gap in communication and giving timeous feedback to students. Some supervisors indicated that they were not familiar with software and programmes such as Zoom, WeChat, video conferencing, Skype and many others. This showed that even though ICTs were being used in most universities some lecturers lacked basic computer skills such as creating an email address let alone using Skype or zoom. This pointed to the fact that the majority of the universities lacked structured or sufficient communication channels resources to cater for both supervisors and the students.

The level of preparedness is also affected by the cost of infrastructure and software. Computers and other related gadgets are expensive. For instance, a basic laptop is costing around USD550.00, which is well above the reach of many. The findings of this study are in agreement with Nasisri \& Mafakheri, 2015; Mapesela \& Wilkinson, 2005; Picard et al., 2011 who indicated that even though it is desirable for lecturers to have internet connectivity the cost is prohibiting.

Level of preparedness by students. Lack of personal conduct between the supervisor and the student especially for students who may be under prepared to undertake a $\mathrm{PhD}$ programme through ODL mode of learning was noted. It observed that there are some $\mathrm{PhD}$ students who are academically weak and may need constant faceface conduct with their supervisors. In order to address this weakness, there is need for experienced supervisors to conduct workshops on ODL mode of education for novice supervisors.

Technology cannot be used to solve some interpersonal relationships between the supervisor and the student and this why ground rules on how to proceed in the doctoral journey is important. When a student is alone, he/she may end up feeling lonely and lost. This may lead to lack of focus and delay in the completion of the programme since there will be no encouragement from peers and probably from the supervisor. Willems, Farley, Ellis, McCormick, \& Walker (2013) note that isolation can negatively impact on the student's engagement and thereby affecting progress.

Supervising at a global level could be great experience provided the supervisor is ready to learn and adopt to new supervision approaches. If this fails, communication and progress may become difficult. Distance covers diversity in students, since ODL transcend borders of countries. This then implies that the supervisor will be faced by students from different cultural 
backgrounds. Diversity in students enables the supervisor to understand and appreciate differences in culture, norms and values and comes up with appropriate approach. In pursuant to the above, strategies need to be put in place so that the work of the supervisor is made easy. The virtual office should remain open in order to cater for time differences in various locations. Students and the supervisor can hold virtual meetings and classes and share notes. Face-to-face integration is the recipe of building good rapport between the supervisor and the student. However, this can be overcome by creating virtual classes and video conferencing.

Level of readiness by universities. Even though all universities in the country have ICT related gadgets and software, they lacked preparedness due to the fact that some faculties, schools and departments where not connected or had weak internet connectivity. The majority of the universities in the country are not prepared to offer ODL programmes complimented with ICT. The majority of the universities that showed lack of preparedness were found to be small and young. However, it should be the dream of every university to be driven by technology since countries are now moving towards knowledgebased economies. One interesting story was drawn from one university that was established in 1992, which had gone to the extent of creating virtual classes and offering online degree programmes regardless of the student's location. The Zimbabwean higher education system used to despise online education citing quality related issues and lack of face-face conduct with the student. It is now a great relief to most prospective students who do not have time to be on compass because of various reasons. This shows that the institution has a well-crafted strategy and understands strategy implemented to support the technologies use and supporting learning and teaching. It is hoped that other local universities are going to follow-suit.

The majority of the universities (6) were found to be lacking in terms of effective and efficient use of technology to enhance learning as a strategic pillar for modern higher education. Most universities did not have statements of intent towards the use of ICT and this could be one of the reasons why most faculties, departments and schools were not committed to the use of technology. It was further observed that four out of ten universities had institution-wide processes for quality assurance in place and the use of technology that was integrated in most in their programmes. What was noted was that the level of preparedness of a university affected the level of preparedness of both the student and the supervisor. Some universities did not have infrastructure and other facilities to support students and supervisors in their work.

The study noted that students and supervisors had poor access to computers and internet as indicated by the majority of the respondents. Universities in Zimbabwe provide students and lecturers with access to ICTs in various forms such as internet and email but all these were found to be limited in four universities universities. Students and supervisors concurred that limited expertise, in adequate funding and disrupted power supplies were the major challenges. It was found that ICT enabled both supervisors and students to deliver and receive lectures through modern technology without affecting standards and quality based on local and international dictates.

Figure 1 shows that one university was not prepared, 2 had limited level of preparedness, 2 had moderate level of preparedness, 3 had extensive level of preparedness and 2 had comprehensive preparedness. This could mean that the level of preparedness of a university also affected the level of preparedness of both the supervisor and student. What could be the ideal is to make sure that there is integration of the teaching and learning aspects with ICTs. There is also need for universities to invest in ICTs since higher education has become the enabler of knowledge-based economises. What is noted is that Zimbabwean universities are on the right track in terms of embracing ICTs in improving quality and throughput of $\mathrm{PhD}$ outcomes. The following section proposed recommendation to all stakeholders in higher education in Zimbabwe. 


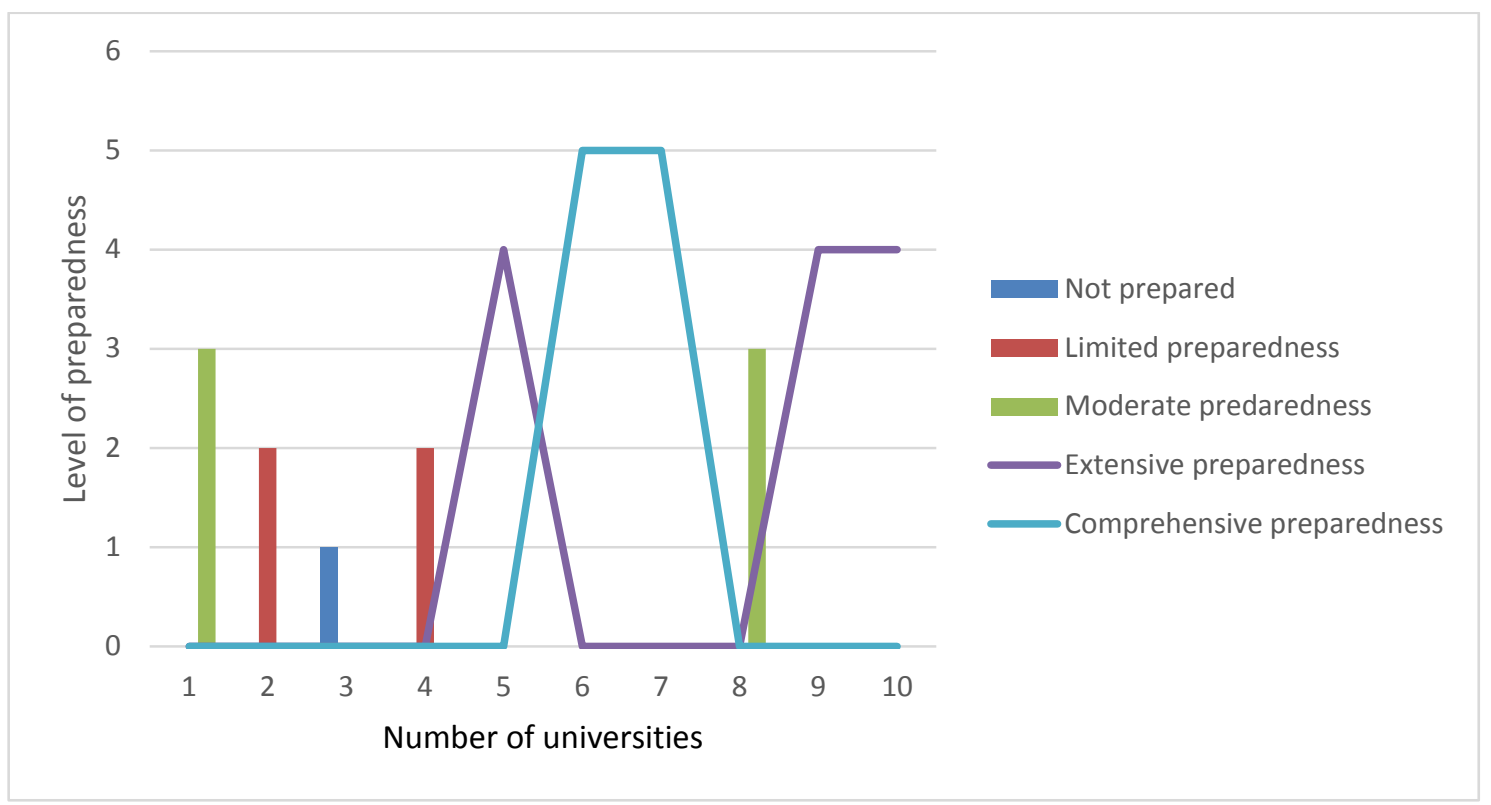

Fig. 1: Rating on the level of ICT integration in the 10 universities

\section{RECOMMENDATIONS}

In view of the findings, it is recommended that universities invest more in ICTs infrastructure and facilities and put in place policies that emphasise the importance of using ICTs since economies have evolved to knowledge-based economies. It is high time that institutions of higher learning develop online courses for supervisors who might be lacking basic computer skills. The use of modern teaching methodologies is key to transforming the Zimbabwean higher education to be in line with best practices. This can further enhances the creation of communities of scholars that transcend physical boundaries. When supervisors are empowered with ICT skills they can supervise $\mathrm{PhD}$ candidates studying through ODL and can achieve the desired outcomes without compromising on quality as evinced by the University of London, University of South African, the Zimbabwe Open University and many others that have embraced and invested in ICTs.

\section{CoNCLUSION}

The study noted that the use of ICT in PhD supervision is the way to go and that some local universities have already embraced the use of ICTs. ICT is a quality enabler in higher education since universities can enrol students who apply from anywhere around the globe. Universities can recruit students from anywhere around the globe as long as they have the prerequisite facilities and resources to support the supervisor and the student. Since not all students can enrol on a fulltime basis, there is urgent need for universities to invest in ICTs infrastructure and facilities for ODL to become a reality. The advent of information and communication technology has changed the face of open and distance learning around the globe. What is appreciated most is that a university through the ICT affordances can create interactive platforms for both students and supervisors beyond the country's borders leading affordability and internationalisation of higher education. The use of information technology will continue to shape the future of higher education around the globe.

\section{REFERENCES}

Allen, A., Stucky, M., \& Thiele, J. (1999). Effects of web-based instruction on learning behaviours of undergraduate and graduate students. Nursing and Health Care Perspectives, 20 (4), 199-203. (in English)

Barket, R., \& Holley, C. (1996). Interactive distance learning: perspectives and thoughts. Business Communication Quarterly, 59 (4), 88-97. (in English)

Bell, R., \& Tight, M. (2003). Open universities: A British tradition? Society for Research into Higher Education. Buckingham: Open University Press. (in English)

City Press. (2019). Zim shuts down internet, social media as fuel protests continue. Retrieved from 
https://city-press.news24.com/News/zim-shutsdown-internet-social-media-as-fuel-protestscontinue-20190115. (in English)

Cross, M., \& Backhouse, J. (2014). Evaluating Doctoral Programmes in Africa: Context and Practices. Higher Education Policy, 27 (2), 155-174. DOI: http://doi.org/10.1057/hep.2014.1. (in English)

Erichsen, E. A., Bolliger, D. U., \& Halupa, C. (2014). Student satisfaction with graduate supervision in doctoral programs primarily delivered in distance education settings. Studies in Higher Education, 39 (2), 321-338. DOI: https://doi.org/10.1080/03075079.2012.709496. (in English)

Frick, L. (2011). Models of Supervision. DIESR/CREST Training Course for Supervisors of Doctoral Candidates at African University. (in English)

Gaba, A. K. (2004). Staff Training and Research Institute of Distance Education Indira Gandhi National Open University. Maidan Garhi, New Delhi. (in English)

Gatfield, T. (2005). An Investigation into $\mathrm{PhD}$ Supervisory Management Styles: Development of a dynamic conceptual model and its managerial implications. Journal of Higher Education Policy and Management, 27 (3), 311-325. DOI: https://doi.org/10.1080/13600800500283585. (in English)

Ghosh, S., Nath, J., Agarwal, Sh., \& Nath, A. (2012). Open and Distance Learning Education System: Past, present and future - A systematic study of an alternative education system. Journal of Global Research in Computer Science, 3(4), 53-57. (in English)

Guilar, J. D., \& Lorring, A. (2008). Dialogue and community in online learning: Lessons from Royal Roads University. International Journal of ELearning \& Distance Education, 22 (3), 19-40. (in English)

Haksever, A. M., \& Manisali, E. (2000). Assessing Supervision Requirements of $\mathrm{PhD}$ Students: The Case of Construction Management and Engineering in the UK. European Journal of Engineering Education, 25, 19-32. (in English)

Jones, M. (2013). Issues in doctoral studies - Forty years of journal discussion: Where have we been and where are we going? International Journal of Doctoral Studies, 8, 83-104. DOI: https://doi.org/10.28945/1871. (in English)

Kumar, R. (2011). Research Methodology: A Step-byStep Guide for Beginners. New Delhi: Sage.

Lazarus, R. S., \& Folkman, S. (1984). Stress, appraisal and coping. New York, NY: Springer. (in English)

Levinson, D. L. (2005). Community colleges: A reference handbook. California: ABC-CLIO. (in English)
Mafa, O., \& Mapolisa, T. (2012). Supervisors' Experiences in Supervising Postgraduate in Education Students' Dissertations and Theses at the Zimbabwe Open University (ZOU). International Journal of Asian Social Science, 2 (10), 1685-1697. (in English)

Manyike, T. V. (2017). Postgraduate supervision at an open distance e-learning institution in South Africa. South African Journal of Education, 37 (2), art. 1354, 1-11. DOI: http://doi.org/10.15700/saje.v37n2a1354. (in English)

Maor, D., Ensor, J. D., \& Fraser, B. J. (2016). Doctoral supervision in virtual spaces: A review of research of web-based tools to develop collaborative supervision. Higher Education Research \& Development, 35 (1), 172-188. DOI: https://doi.org/10.1080/07294360.2015.1121206. (in English)

Mapesela, M. L. E, \& Wilkinson, A. C. (2005). The pains and gains of supervising postgraduate students from a distance: The case of six students from Lesotho. South African Journal for Higher Education, 19, 1238-1254. DOI: http://doi.org/10.4314/sajhe.v19i7.50227. (in English)

Moore, M. (1989). Editorial: Three types of interactions. The American Journal of Distance Education, 3(2), 1-6. DOI: https://doi.org/10.1080/08923648909526659. (in English)

Mouton, J. (2011). Doctoral production in South Africa: statistics, challenges and responses. Perspectives in Education, 29 (3), 13-29.

Nasisri, F., \& Mafakheri, F. (2015). Postgraduate research supervision at a distance: a review of challenges and strategies. Studies in Higher Education, 40 (10), 1962-1969. DOI: https://doi.org/10.1080/03075079.2014.914906. (in English)

Pearce, L. (2005). How to Examine a Thesis. New York Society for Research into Higher Education and Open University. Perspectives in Education, 29 (1), 13-29. (in English)

Picard, M. Y., $\quad$ Wilkinson, K., $\quad \& \quad$ Wirthensohn, M. (2011). An online learning space facilitating supervision pedagogies in science. South African Journal of Higher Education, 25(5), 954-971. (in English)

Pittman, V. V. (2006). Correspondence study in the American university: A second historiographical perspective. In M. G. Moore, \& W. G. Anderson (Eds.), Handbook on distance education (pp. 21-35). New York: Sage. (in English) 
Second World Conference on Research Integrity (2010). Singapore Statement on Research Integrity. Retrieved from https://www.jsps.go.jp/english/ekousei/data/singapore_statement_EN.pdf. (in English)

Tait, A. (2003). Reflections on student support in open and distance learning. The International Review of Research in Open and Distributed Learning, 4 (1), 134-164. (in English)

University of London (2012). International programmes. About us. Retrieved from https://london.ac.uk/about-us/our-globalreputation. (in English)

Willems, J., Farley, H., Ellis, A. H., McCormick, D., \& Walker, D. (2013). Supervising higher degree research (HDR) candidates at a distance: What do emerging virtual world technologies have to offer?.
In B. Tynan, J. Willems, \& R. James (Eds.), Outlooks and Opportunities in Blended and Distance Learning (pp. 369-382). Hershey, PA: IGI Global. DOI: http://doi.org/10.4018/978-1-4666-4205-8.ch027. (in English)

Wisker, G., Robinson, G., Trafford, V., Creighton, E., \& Warnes, M. (2003). Recognising and overcoming dissonance in postgraduate student research. Studies in Higher Education, 28 (1), 91-105. DOI: https://doi.org/10.1080/03075070309304. (in English)

Zuppo, C. M. (2012). Defining ICT in a Boundaryless World: The Development of a Working Hierarchy. International Journal of Managing Information Technology, $4(3)$, 13-22. DOI: http://doi.org/10.5121/ijmit.2012.4302. (in English)

About the authors:

Promise Zvavahera, PhD, Reformed Church University, Faculty of Commerce (Masvingo, Zimbabwe), promisezvavahera59@gmail.com

Fine Masimba, Catholic University of Zimbabwe, Faculty of Commerce (Harare, Zimbabwe), fmasimba@cuz.ac.zw 